\title{
CONVENTIONAL AND MOLECULAR TYPING OF Salmonella TYPHI STRAINS FROM BRAZIL
}

\author{
Bianca R. QUINTAES(1,2), Nilma C. LEAL(3), Eliane M. F. REIS(1), Érica L. FONSECA(1) \& Ernesto HOFER(1)
}

\begin{abstract}
SUMMARY
Phenotypic and genotypic characteristics of Salmonella Typhi were studied in 30 strains, isolated in different years, from some areas in Brazil. Conventional typing methods were performed by biochemical tests, Vi phage-typing scheme, and antimicrobial susceptibility test. Molecular typing methods were performed by analysis of plasmid DNA and by random amplified polymorphic DNA (RAPD-PCR). For the latter, an optimization step was performed to ensure the reproducibility of the process in genetic characterization of $S$. Typhi. The predominance of $76.7 \%$ of biotype I (xylose +, arabinose -) was noticed in all studied areas. Three phage types were recognized, with prominence for the phage types A $(73.3 \%)$ and I+IV $(23.3 \%)$. All the strains were susceptible to the drugs used. However, $36.7 \%$ of the strains contained plasmids, with predominance of the $105 \mathrm{~Kb}$ plasmid. RAPD was capable of grouping the strains in 8 genotypic patterns using primer 784, in 6, using primer 787 and in 7, using primer 797. Conventional phenotypic typing methods, as well as the DNA plasmid analysis, presented nonsignificant discriminatory power; however, RAPDPCR analysis showed discriminatory power, reproducibility, easy interpretation and performance, being considered as a promising alternative typing method for $S$. Typhi.
\end{abstract}

KEYWORDS: Typing; Salmonella Typhi; Vi Phage-typing; Random Amplified Polymorphic DNA-Polymerase Chain Reaction; Brazil.

\section{INTRODUCTION}

Salmonella Typhi is noteworthy in the etiology of outbreaks and sporadic cases of typhoid fever, which remains as an important public health problem, causing 16 to 17 million cases of the disease and about 600,000 deaths, annually, all over the world ${ }^{26}$. The investigation of the epidemiology of $S$. Typhi is, therefore, relevant, mainly in those areas where typhoid fever is endemic, resulting in a clear evaluation about the dissemination of strains and the establishment of prophylactic strategies.

However, the differentiation of strains based on specific markers is critical in the epidemiologic studies of $S$. Typhi; unfortunately, few markers have been described, with Vi phage-typing currently providing the only useful means of distinguishing one $S$. Typhi strain from another ${ }^{14,27}$. Molecular methods for characterization of $S$. Typhi strains have been developed and improved to complement Vi phage-typing and allow the differentiation of non-related strains that belong to the same phage type, for example, multilocus enzyme electrophoresis ${ }^{19}$, ribotyping ${ }^{1}$, and pulsed field gel electrophoresis - PFGE ${ }^{16}$. However, these techniques are all time consuming and technically demanding. A PCR-based typing method, RAPD-PCR (Random Amplified Polymorphic DNA), has been described as a simple and rapid method able to offer detailed fingerprinting of the genomic composition of the organism $^{28,29}$. The success of this method is due to the fact that no prior sequence information about the target is needed and a single short 10mer oligonucleotide primer can be used in the reaction. The amplification happens at low stringency, allowing the primers to anneal to several locations on the two strands of the DNA. These primers detect polymorphisms in the absence of specific sequence information and the DNA sequence variations may work as genetic markers that can be used in epidemiologic studies.

In the present study the conventional system for typing $S$. Typhi (biotyping, antimicrobial susceptibility and Vi phage-typing) was evaluated and its performance compared to molecular typing methods (plasmid and RAPD-PCR analysis).

\section{MATERIALS AND METHODS}

$S$. Typhi strains were isolated from blood (Table 1) and maintained in stock agar cultures ${ }^{8}$ at National Reference Center for Cholera and Enteric Diseases, Department of Bacteriology of Oswaldo Cruz InstituteFiocruz. For molecular analysis, the strains were preliminarily grown in Brain Heart Infusion (Difco) for $24 \mathrm{~h}$ at $37^{\circ} \mathrm{C}$.

The strains were confirmed as $S$. Typhi by the biochemical characteristics and serotyped based on the Antigenic Formulas of the Salmonella serovars ${ }^{18}$. The organisms were further investigated for

(1) Departamento de Bacteriologia, Instituto Oswaldo Cruz-Fiocruz, 21045-900 Rio de Janeiro, RJ, Brasil.

(2) Departamento de Microbiologia Médica, Curso de Pós-graduação, Universidade do Estado do Rio de Janeiro, RJ, Brasil.

(3) Laboratório de Microbiologia, Centro de Pesquisas Aggeu Magalhães-Fiocruz, Recife, PE, Brasil.

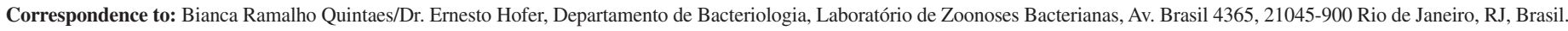


fermentation of d-xylose and 1-arabinose. According to the classification proposed by KRISTENSEN \& HENRIKSEN ${ }^{12}$ and KRISTENSEN ${ }^{13}$, $S$. Typhi strains can be classified as biotypes I (arabinose -, xylose +), II (arabinose -, xylose -), III (arabinose + , xylose + ), and IV (arabinose + , xylose-). Susceptibilities to antimicrobial agents were determined by using the high-potency disk diffusion method ${ }^{3}$. The included antibiotics were ampicillin $(10 \mu \mathrm{g})$, ceftriaxone $(30 \mu \mathrm{g})$, ciprofloxacin $(5 \mu \mathrm{g})$, gentamicin $(10 \mu \mathrm{g})$, chloramphenicol $(30 \mu \mathrm{g})$, tetracycline $(30 \mu \mathrm{g})$ and trimethoprim-sulfamethoxazole $(25 \mu \mathrm{g})$.

Phage types were determined using the technique of CRAIGIE \& YEN $^{6}$, modified by CRAIGIE \& FELIX ${ }^{5}$, and ANDERSON \& WILLIAMS $^{2}$. The phage preparations were kindly provided by the International Reference Laboratory for Enteric Phage Typing, Colindale, London.

Plasmid DNA was extracted using the BIRNBOIM \& DOLY's ${ }^{4}$ method. Electrophoretic separation of plasmid species by molecular weight and subsequent size estimations were accomplished using reference strains Escherichia coli V517 and 39R861.

The RAPD analysis was preceeded by total DNA extraction as described by MANIATIS et al. ${ }^{15}$, using $1 \mathrm{ml}$ of an overnight culture of each strain. The DNA was quantified, after electrophoresis in a $1 \%$ agarose gel, by comparison with known amounts of Hind III digested bacteriophage $\lambda$ DNA. The genetic material was mantained stable for about four weeks, stored at $-4{ }^{\circ} \mathrm{C}$. For RAPD-PCR analysis, some parameters of the reaction such as $\mathrm{MgCl}_{2} \cdot 6 \mathrm{H}_{2} \mathrm{O}$, DNA template, primer and $T a q$ DNA polymerase enzyme concentrations were optimized in order to maximize the discriminatory power of the reaction for typing $S$. Typhi, allow reproducibility, and facilitate the interpretation of amplified bands. Using an isolate genomic DNA as template [(IOC 501) - Oswaldo Cruz Institute collection] for the optimization steps, assays were made with oligonucleotides primers commercially synthesized to test their ability to produce discriminatory RAPD profiles in Salmonella Typhi. A set of 16 primers synthesized by Escola Paulista de Medicina (São Paulo, Brazil) was analyzed and based on the accurate amplified bands profiles and the produced polymorphic patterns of DNA fingerprinting we selected three different primers: 784 - 5'GCG GAA ATA G 3'; 787 5'AAC GCG CAA C 3' and 797 - 5'AGC GTC ACT C 3'.

The reaction was prepared using $25 \mu \mathrm{l}$ per tube, containing $20 \mathrm{ng}$ DNA of each strain, 1 unit of Taq DNA polymerase enzyme (CENBIOT/ RS), $10 \mathrm{mM}$ Tris $\mathrm{HCl}, 50 \mathrm{mM} \mathrm{KCL}, 2.0 \mathrm{mM} \mathrm{MgCl}, 200 \mathrm{mM}$ of each $\mathrm{dNTP}$, and $20 \mathrm{pmol}$ of primer. It was carried out in a thermal cycler programmed for 30 cycles composed of one step of denaturation for 1 min at $94{ }^{\circ} \mathrm{C}$, one step of annealing for $1 \mathrm{~min}$ at $36^{\circ} \mathrm{C}$ followed by one step of synthesis for $2 \mathrm{~min}$ at $72{ }^{\circ} \mathrm{C}$. These conditions were previously evaluated in an optimization step.

Amplification products were submitted to electrophoresis in $1.5 \%$ agarose gel, Tris-borate buffer, and a constant voltage of $100 \mathrm{~V}$, followed by staining with ethidium bromide and visualization by means of a UV transilluminator. A negative control was included in each PCR run with no target DNA. The $\lambda$ phage DNA cleaved by Hind III restriction enzyme (Sigma) and the synthetic DNA, ladder 100 (Pharmacia) were employed as molecular markers for bands weight.

\section{RESULTS}

Among the $30 \mathrm{~S}$. Typhi strains analyzed, two biotypes, I and II, were recognized. Biotype I predominated and accounted for $76.7 \%$ of the observed biotypes (Table 1). Phage type A was the most prevalent type identified and comprised $73.3 \%$ of the 30 strains analyzed by Vi phage-typing. In the Southeast and Northeast regions only phage type A was observed regardless the year when the strains were isolated. Phage type I+IV was prevalent in the North region and the type 46 was evident in one of the four strains isolated in the Middle-West region and, although a few number of strains was assayed, this region showed a considerable diversity by using Vi phage-typing. According to the antimicrobial tests, all the isolates displayed sensibility to the drugs used.

Plasmid DNA of $S$. Typhi isolates was identified according to its molecular weight in kilobase (Kb). A total of $36.7 \%$ of the analyzed isolates showed plasmids and it was possible to distinguish four different profiles. Molecular weights plasmids varied from 4.2 to $105 \mathrm{~Kb}$, but plasmids 16.5 and $105 \mathrm{~Kb}$ were prevalents. The majority of strains $(63.3 \%)$ did not show any plasmid even in a second analysis. The amplifications with primer 784 divided the 30 analyzed strains into 8 distinct RAPD profiles (Fig. 1), revealing fragments ranging from 350 to $3000 \mathrm{bp}$. The profile R4 was prevalent in $30 \%$ of the strains (Table 1). Primer 787 divided the strains into 6 profiles (Fig. 2), showing less polymorphic bands with fragments ranging from 450 to $2800 \mathrm{bp}$. The profile D1 was predominating (70\%) (Table 1). We identified seven different profiles generated by primer 797 (Fig. 3) and the prevalence of profile G1 in $53.3 \%$ of the tested strains. This primer produced fragments ranging from 250 to $3000 \mathrm{bp}$ and revealed a great number of bands for each profile. When the combination of amplification products patterns, generated by different primers was used to subtype $S$. Typhi strains, we found out a high diversity and it was possible to divide them into 21 distinct types.

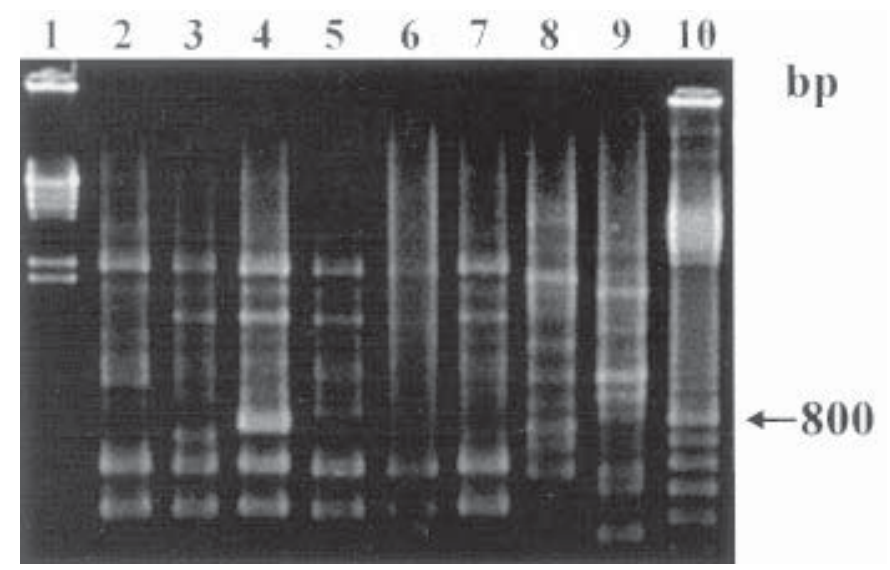

Fig. 1 - Representative profiles generated by RAPD-PCR using primer 784. Lanes: 1, Hind III digested bacteriophage $\lambda$ DNA; 2 , RAPD profile R1; 3 , RAPD profile R2; 4, RAPD profile R3; 5, RAPD profile R4; 6, RAPD profile R5; 7, RAPD profile R6; 8, RAPD profile R7; 9, RAPD profile R8; 10, "Ladder" 100 DNA. 


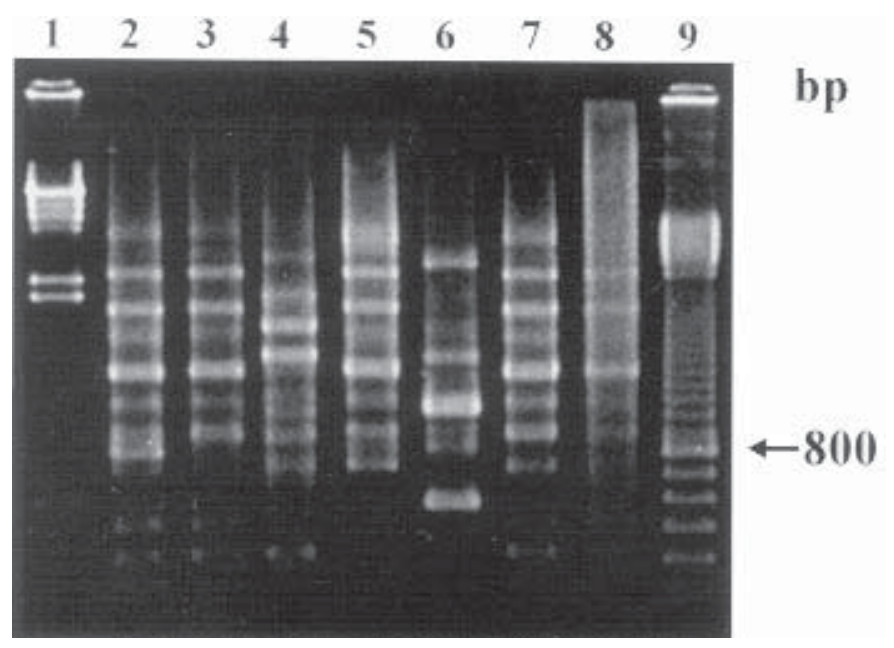

Fig. 2 - Representative profiles generated by RAPD-PCR using primer 787. Lanes: 1, Hind III digested bacteriophage $\lambda$ DNA; 2 , RAPD profile D1; 3 , RAPD profile D2; 4, RAPD profile D3; 5, RAPD profile D4; 6, RAPD profile D5; 7, RAPD profile D6; 8, "Ladder" 100 DNA.

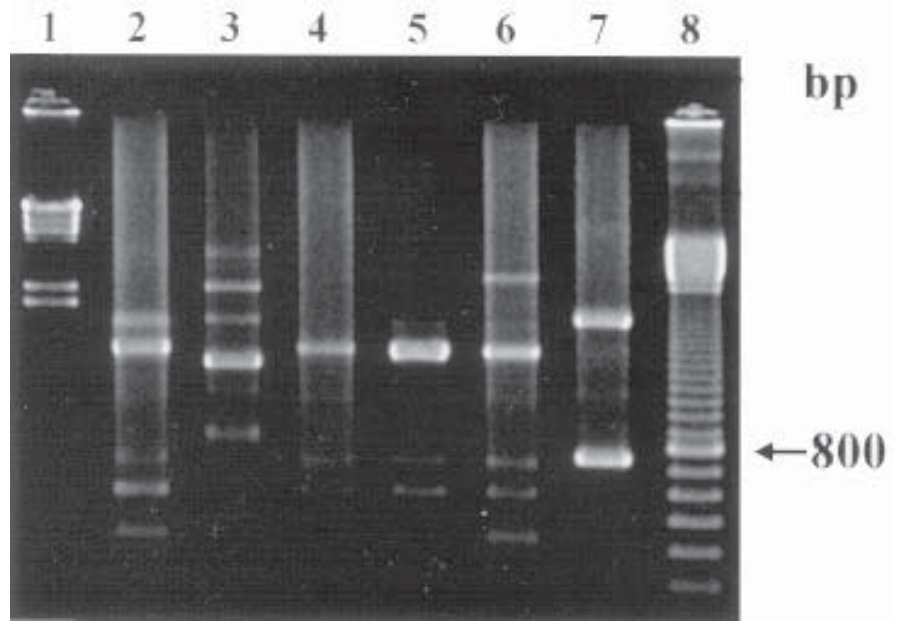

Fig. 3 - Representative profiles generated by RAPD-PCR using primer 797. Lanes: 1, Hind III digested bacteriophage $\lambda$ DNA; 2 , RAPD profile G1; 3, RAPD profile G2; 4, RAPD profile G3; 5, RAPD profile G4; 6, RAPD profile G5; 7, RAPD profile G6; 8, RAPD profile G7; 9, "Ladder" 100 DNA.

Table 1

Phenotypic and genotypic characteristics of $S$. Typhi strains isolated from different geographic areas of Brazil

\begin{tabular}{|c|c|c|c|c|c|c|c|c|}
\hline $\begin{array}{c}\text { Strain } \\
\text { Number }\end{array}$ & Area & Year & Biotype & $\begin{array}{c}\text { Vi phage } \\
\text { Type }\end{array}$ & $\begin{array}{l}\text { Plasmid } \\
\text { Profile }\end{array}$ & $\begin{array}{c}\text { RAPD } \\
\text { Primer } 784\end{array}$ & $\begin{array}{c}\text { RAPD } \\
\text { Primer } 787\end{array}$ & $\begin{array}{c}\text { RAPD } \\
\text { Primer } 797\end{array}$ \\
\hline 475 & North & 1995 & I & $\mathrm{A}$ & - & R5 & D1 & $\mathrm{G} 2$ \\
\hline 479 & North & 1995 & I & A & - & $\mathrm{R} 4$ & D1 & G6 \\
\hline 492 & North & 1995 & I & $\mathrm{I}+\mathrm{IV}$ & - & $\mathrm{R} 4$ & D1 & G1 \\
\hline 493 & North & 1995 & I & $\mathrm{I}+\mathrm{IV}$ & - & $\mathrm{R} 4$ & D1 & G1 \\
\hline 496 & North & 1995 & I & $\mathrm{I}+\mathrm{IV}$ & - & $\mathrm{R} 4$ & D1 & $\mathrm{G} 2$ \\
\hline 499 & North & 1995 & I & $\mathrm{I}+\mathrm{IV}$ & - & $\mathrm{R} 4$ & D1 & G1 \\
\hline 500 & North & 1995 & I & $\mathrm{I}+\mathrm{IV}$ & - & R4 & D1 & G6 \\
\hline 501 & North & 1995 & I & $\mathrm{I}+\mathrm{IV}$ & - & $\mathrm{R} 4$ & D3 & G1 \\
\hline 653 & North & 1995 & I & A & $\mathrm{P} 2$ & R6 & D3 & G1 \\
\hline 30 & Middle-West & 1972 & II & $\mathrm{I}+\mathrm{IV}$ & - & $\mathrm{R} 1$ & D4 & G6 \\
\hline 31 & Middle-West & 1972 & II & 46 & - & $\mathrm{R} 8$ & D6 & G5 \\
\hline 655 & Middle-West & 1995 & I & A & $\mathrm{P} 1$ & R5 & D1 & G1 \\
\hline 656 & Middle-West & 1995 & I & A & $\mathrm{P} 2$ & R5 & D1 & $\mathrm{G} 2$ \\
\hline 59 & Southeast & 1970 & I & A & $\mathrm{P} 2$ & R6 & D1 & G1 \\
\hline 94 & Southeast & 1970 & I & A & - & R6 & D1 & $\mathrm{G} 2$ \\
\hline 74 & Southeast & 1972 & II & A & $\mathrm{P} 4$ & $\mathrm{R} 2$ & D5 & G1 \\
\hline 174 & Southeast & 1972 & I & A & - & $\mathrm{R} 4$ & D1 & $\mathrm{G} 1$ \\
\hline 154 & Southeast & 1972 & I & A & $\mathrm{P} 4$ & R6 & D5 & G4 \\
\hline 137 & Southeast & 1972 & II & A & $\mathrm{P} 4$ & $\mathrm{R} 2$ & D5 & G1 \\
\hline 201 & Southeast & 1972 & I & A & $\mathrm{P} 4$ & $\mathrm{R} 2$ & D5 & G1 \\
\hline 665 & Southeast & 1990 & I & A & P3 & R7 & D2 & G3 \\
\hline 708 & Southeast & 1996 & II & A & - & R5 & D1 & G6 \\
\hline 721 & Southeast & 1996 & II & A & - & $\mathrm{R} 2$ & D1 & G1 \\
\hline 719 & Southeast & 1996 & I & A & - & R5 & D1 & G7 \\
\hline 652 & Southeast & 1996 & I & A & - & R3 & D1 & G4 \\
\hline T06 & Northeast & 1927 & II & A & - & R6 & D1 & G1 \\
\hline T68 & Northeast & 1937 & I & $\mathrm{A}$ & - & R3 & D1 & G1 \\
\hline $\mathrm{T} 79$ & Northeast & 1937 & I & A & $\mathrm{P} 1$ & R3 & D1 & G1 \\
\hline T54 & Northeast & 1938 & I & A & - & R3 & D1 & G1 \\
\hline T93 & Northeast & 1938 & I & A & P1 & $\mathrm{R} 4$ & D1 & G7 \\
\hline
\end{tabular}

- No plasmids identified 


\section{DISCUSSION}

The presence of $S$. Typhi in Brazilian areas as a recurrent pathogen and as the cause of typhoid fever worldwide has determined the need to monitor the epidemic spread of this microorganism. Vi phage-typing has been the most commonly conventional technique used to type $S$. Typhi, despite several disadvantages: it is technically demanding; there is a significant proportion of non phage typable strains (Vi degradable); there are some Vi negative strains; and the technique can only be suitably performed by the reference laboratories that harbor all the Vi phage preparations ${ }^{1}$. More recently, molecular techniques for typing microorganisms have had an important advance and a great number of techniques has been standardized and applied to type $S$. Typhi. RAPDPCR has successfully been applied to molecular fingerprinting; it uses single primers of arbitrary nucleotide sequence able to access random segments of genomic DNA to reveal polymorphisms ${ }^{28,29}$. The resulting genetic fingerprint can be of epidemiologic value. This makes it a powerful typing method that can determine genomic diversity. Nevertheless, for the analysis of $S$. Typhi, few data have been published on the applicability of the RAPD method ${ }^{21}$.

The analysis of $S$. Typhi by Vi phage-typing divided the strains into three distintic types: A, I+IV and 46. The detection of phage type 46 in the Middle-West area is presumed by the presence of imported cases and its relation to South American countries ${ }^{10,11}$. For example, most of the isolates from Santiago, Chile, belongs to phage type $46^{25}$. For the strains isolated in southeastern and northeastern areas, the application of Vi phage-typing was limited since only phage type A was identified. The prevalence of type A has already been detected in some Brazilian states such as São Paulo, Rio de Janeiro, and Pernambuco ${ }^{10}$ and also in $S$. Typhi strains isolated from Malaysia, Singapore, and Indonesia ${ }^{30}$. Phage type occurrence follows a geographic distribution ${ }^{18}$ and types A and I+IV are considered of world wide distribution. This highlighted the necessity of more discriminatory methods to complement Vi phagetyping, particularly when only one phage type is present.

Plasmid profiles proved not to be a good epidemiological marker for $S$. Typhi when analysing strains from different areas and years. The analysis of $S$. Typhi plasmids would be more suitable to characterize their temporal occurrence in an endemic setting and their possible association with the typhoid fever severity ${ }^{7}$, as well as for analysis of outbreaks of nosocomial infections. Plasmid profiles are not very useful for subtyping S. Typhi since less than $10 \%$ of the strains, in general, harbor plasmids ${ }^{24}$. Indeed, we found that only $36.7 \%$ of the strains tested showed plasmids and no relation was found between these plasmids and antibiotic resistance. This could be explained as a result of plasmid instability in $S$. Typhi, rather than an inherent barrier to the entry or establishment of foreign plasmid DNA ${ }^{14}$.

The clonal nature of $S$. Typhi has been of interest to many researches. As reported before, clones are considered genetically related isolates that are indistinguishable from each other by a variety of genetic tests (e.g., PFGE, multilocus enzyme electrophoresis, or ribotyping) ${ }^{22}$. Based on enzyme genotypic identity, $S$. Typhi has been considered as member of a single clone of world wide distribution ${ }^{19,20}$. However, we found diversity among the strains analyzed by RAPD-PCR despite the relatively small number of oligonucleotides primers (3) used. To interpret the DNA fragment patterns generated by RAPD-PCR, we should understand that the occurrence of random genetic events, including point mutation and insertions and deletions of DNA, can alter the RAPD fingerprinting patterns ${ }^{23}$. For this reason, we presumed the differentiating bands in the profiles could be due to one or more genetic events (Fig. 1, 2 and 3).

The discriminatory power of RAPD was tested by considering the number of profiles generated, both with each primer separately, and combining the results obtained with the three primers (Table 1). When the RAPD profiles were analyzed considering the temporal occurrence, the persistence of some profiles was evident in all years, as for D1 and G1. The evidence of profile R4D1G1 isolated in 1972 in the Southeast region and in 1995 in the North region may indicate the emergence and the circulation of this strain. Furthermore, the results suggested that some strains disappeared and returned in time and space. Once the same optimized conditions were applied to all the strains, resulting in different profiles, the more suitable analysis of the results should be done considering the final profile obtained combining the primers 784,787 and 797. The employment of other primers could increase the possibilities to detect DNA sequence variations.

The traditional phenotypic typing methods used (antibiogram typing, biotyping and Vi phage-typing) showed low discriminatory power. RAPD-PCR analysis showed to have the potential to provide a discriminatory, reproducible, low cost, easy to perform and interpret method to type $S$. Typhi strains.

\section{RESUMO}

\section{Métodos convencionais e moleculares para tipagem de Salmonella Typhi isoladas no Brasil}

Características fenotípicas e genotípicas de Salmonella Typhi foram estudadas em 30 amostras originárias de certas regiões do Brasil e isoladas em diferentes anos. Os métodos convencionais foram realizados através da tipagem bioquímica, da fagotipagem Vi e do teste de suscetibilidade aos antimicrobianos. Os métodos moleculares foram realizados através das análises do DNA plasmidial e do DNA polimórfico amplificado aleatoriamente (RAPD-PCR). Para este último, uma etapa de otimização foi promovida para garantir a reprodutibilidade do processo na caracterização genotípica das cepas. Foi observada a predominância de $76,7 \%$ do biotipo I (xilose +, arabinose -) em todas as regiões consideradas. Três fagotipos foram reconhecidos, com destaque para os fagotipos A $(73,3 \%)$ e I+IV (23,3\%). Todas as amostras demonstraram sensibilidade às drogas testadas. No entanto, 36,7 \% das amostras evidenciaram plasmídios, predominando o de $105 \mathrm{~Kb}$. RAPD-PCR agrupou as amostras em 8 perfis genotípicos com o iniciador 784, em 6 perfis com o iniciador 787 e em 7, com o iniciador 797. Os métodos convencionais, bem como a análise do DNA plasmidial, não mostraram poder discriminatório significativo; entretanto, a análise por RAPD-PCR mostrou poder discriminatório, reprodutibilidade, fácil interpretação e execução, sendo considerada uma alternativa promissora na tipagem de S. Typhi.

\section{ACKNOWLEDGEMENTS}

The authors thank Mrs. Deise Paranhos Feitosa, Mr. Junair Ribeiro, Mr. Evaldo Soares da Silva, Mrs. Yara Maria Maia Nakasawa and Mrs. Silvana Santos for excellent technical assistance. We are also grateful to 

44(6):315-319, 2002.

Dra. Alzira Maria Paiva de Almeida and Dra. Dália dos Prazeres Rodrigues for the facilities offered for the conduction of this research.

\section{REFERENCES}

1. ALTWEGG, M.; BRENNER, F.W.H. \& FARMER III, J.J. - Ribosomal RNA gene restriction patterns provide increased sensitivity for typing Salmonella typhi strains. J. infect. Dis., 160: 145-149,1989.

2. ANDERSON, E.S. \& WILLIAMS, R.E.O. - Bacteriophage typing of enteric pathogens and Staphylococci and its use in epidemiology. J. clin. Path., 9: 94-127, 1956

3. BAUER, A.W.; KIRBY, W.M.; SHERRIS, J.C. \& TURCK, M. - Antibiotic susceptibility testing by a standardized single disk method. Amer. J. clin. Path., 45: 493-496, 1966.

4. BIRNBOIM, H.C. \& DOLY, J.A. - Rapid alkaline extraction procedure for screening recombinant plasmid DNA. Nucleic Acid Res., 7: 1513-1523, 1979.

5. CRAIGIE, J. \& FELIX, A. - Typing of typhoid bacilli with Vi bacteriophage. Lancet, 252: 823-827, 1947.

6. CRAIGIE, J. \& YEN, C.H. - Demonstration of types of B. typhosus by means of preparations of type II Vi phage: principles and techniques. Canad. J. publ. HIth., 29: 448-463, 1938.

7. FINCH, M.J.; FRANCO, A.; GOTUZZO, E. et al. - Plasmids in Salmonella typhi in Lima, Peru, 1987-1988: epidemiology and lack of association with severity of illness or clinical complications. Amer. J. trop. Med. Hyg., 47: 390-396, 1992.

8. HOFER, E. - Técnicas empregadas no isolamento e caracterização bioquímica. In: COSTA, G.A. \& HOFER, E. Isolamento e identificação de Enterobactérias. Rio de Janeiro, Instituto Oswaldo Cruz, 1972. p. 1-70.

9. HOFER, E.; PESSOA, G.V.A.; MORAIS, J.S. et al. - Considerações sobre o estudo bacteriológico de amostras de Salmonella typhi isoladas em um surto epidêmico de febre tifóide ocorrido no município de São Paulo, Brasil. Rev. Inst. Adolfo Lutz, 34: 53-67, 1974.

10. HOFER, E. - Salmonella typhi: lisotipia Vi e biotipificação em amostras oriundas de algumas regiões do Brasil. Mem. Inst. Oswaldo Cruz, 79: 125-137, 1984.

11. HOFER, E.; REIS, E.M.F.; PUENTE, A.P.; OLIVEIRA, M.A. \& SOLARI, C.A. - Typhoid fever caused by a negative lysine decarboxylase Salmonella Typhi strain in two patients from Distrito Federal, Brazil. Mem. Inst. Oswaldo Cruz, 85: 481-482, 1990.

12. KRISTENSEN, M. \& HENRIKSEN, H.C.D. - Reactions fermentatives du bacille typhique et leur rôle epidémiologique. Acta path. microbiol. scand., 3: 551-582, 1926.

13. KRISTENSEN, M. - Studies on the type division of the typhoid and paratyphoid B bacilli by fermentations. J. Hyg., 38: 688, 1938.

14. MAHER, K.O'.D.; MORRIS, J.G.; GOTUZZO, E. et al - Molecular techniques in the study of Salmonella typhi in epidemiologic studies in endemic areas: comparison with Vi phage typing. Amer. J. trop. Med. Hyg., 35: 831-835, 1986.

15. MANIATIS, T.; FRITSCH, E.F. \& SAMBROOK, J. - Molecular cloning, a laboratory manual. Cold Spring Harbor, Cold Spring Harbor Laboratory, 1982. p. 368-369.

16. NAIR, S.; POH, C.L.; LIM, Y.S.; TAY, L. \& GOH, K.T. - Genome fingerprinting of Salmonella typhi by pulsed-field gel electrophoresis for subtyping common phage types. Epidem. Infect., 113: 391-402, 1994.
17. NICOLLE, P. \& PRUNET, J. - Les lysotypes éxotiques du bacille typhique. Bull. Soc. Path. éxot., 58: 695-714, 1965.

18. POPOFF, M.Y. \& LE MINOR, L. - Antigenic formulas of the Salmonella serovars. 6. ed. Paris, Institut Pasteur; WHO Collaborating Center for Reference and Research for Salmonella, 1997.

19. REEVES, M.W.; EVINS, G.M.; HEIBA, A.A.; PLIKAYTIS, B.D. \& FARMER III, J. J. - Clonal nature of Salmonella typhi and its genetic relatedness to other Salmonellae as shown by multilocus enzyme electrophoresis, and proposal of Salmonella bongori comb. nov. J. clin. Microbiol., 27: 313-320, 1989.

20. SELANDER, R.K.; BELTRAN, P.; SMITH, N.H. et al - Evolutionary genetic relationships of clones of Salmonella serovars that cause human typhoid and other enteric fevers. Infect. Immun., 58: 2262-2275, 1990.

21. SHANGKUAN, Y.H. \& LIN, H.C. - Application on random amplified polymorphic DNA analysis to differentiate strains of Salmonella typhi and other Salmonella species. J. appl. Microbiol., 85: 693-702,1998

22. TENOVER, F.C.; ARBEIT, R.D.; GOERING, R.V. et al - Interpreting chromosomal DNA restriction patterns produced by pulsed-field gel electrophoresis. J. clin. Microbiol., 33: 2233-2239, 1995.

23. TENOVER, F.C.; ARBEIT, R.D. \& GOERING, R.V. - How to select and interpret molecular strain typing methods for epidemiological studies of bacterial infections: a review for healthcare epidemiologists. Molecular typing working group of the Society for Healthcare Epidemiology of America. Infect. Control Hosp. Epidem. 18: 426-439, 1997.

24. THONG, K.L.; CHEONG, Y.M.; PUTHUCHEARY, S.; KOH, C.L. \& PANG, T. Epidemiologic analysis of sporadic Salmonella typhi isolates and those from outbreaks by pulsed-field gel electrophoresis. J. clin. Microbiol., 32: 1135-1141, 1994.

25. THONG, K.L.; CORDANO, A.M.; YASSIN, R.M. \& PANG, T. - Molecular analysis of environmental and human isolates of Salmonella typhi. Appl. environ. Microbiol., 62: 271-274, 1996.

26. THONG, K.L.; PUTHUCHEARY, S.; YASSIN, R.M. et al - Analysis of Salmonella typhi isolates from southeast Asia by pulsed-field gel electrophoresis. J. clin. Microbiol., 33: 1938-1941, 1995.

27. THRELFALL, E.J.; TORRE, E.; WARD, L.R. et al - Insertion sequence IS200 fingerprinting of Salmonella typhi: an assessment of epidemiological applicability. Epidem. Infect., 112: 253-261, 1994.

28. WELSH, J. \& McCLELLAND, M. - Genomic fingerprinting using arbitrarily primed PCR and a matrix of pairwise combinations of primers. Nucl. Acids Res., 19: 52755279, 1991.

29. WILLIAMS, J.G.K.; KUBELIK, A.R.; LIVAK, K.J.; RAFALSKI, J.A. \& TINGEY, S.V. - DNA polymorphisms amplified by arbitrary primers are useful as genetic markers. Nucleic Acids Res., 18: 6531-6535, 1990

30. YEW, F.S.; GOH, K.T. \& LIM, Y.S. - Epidemiology of typhoid fever in Singapore. Epidem. Infect., 110 : 63-70, 1993.

Received: 14 March 2002

Accepted: 30 September 2002 